\section{SOI: $1.1 /$ TAS DOI: $10.15863 /$ TAS International Scientific Journal Theoretical \& Applied Science}

\author{
p-ISSN: 2308-4944 (print) e-ISSN: 2409-0085 (online) \\ Year: 2017 Issue: 11 Volume: 55 \\ Published: $16.11 .2017 \quad \underline{\text { http://T-Science.org }}$
}

SECTION 23. Agriculture. Agronomy. The technique.
Zhanar Yeraliyeva

Department of Biology,

Kazakh State Women's Teacher Training University, Almaty, Republic of Kazakhstan zhanara10-80@mail.ru

Murat Kunelbayev

Department of Physics,

Kazakh State Women's Teacher Training University, Almaty, Republic of Kazakhstan murat7508@yandex.kz

Gaukhar Baitasheva

Department of Biology,

Kazakh State Women's Teacher Training University, Almaty, Republic of Kazakhstan

Altay Kydyrov Kazakh Research Institute of Agriculture and Plant growing, Almaty,

Republic of Kazakhstan

\title{
THE INFLUENCE OF AGRICULTURAL TECHNOLOGY ON THE CULTIVATION OF WINTER WHEAT DURING DRIP IRRIGATION IN THE SOUTHEAST OF KAZAKHSTAN
}

\begin{abstract}
The article deals with the study of agricultural techniques of cultivation of new varieties of winter wheat under drip irrigation. For the implementation of tasks in 2014 were sown 2 lines of new varieties of winter wheat. Study of the reaction of new winter wheat varieties under drip irrigation showed that super wheat SWW 1/904 and 1/97, having a large size of the photosynthetic organ, dry biologically harvest reached 167,2-172,8 c/ha. Definition at super winter wheat photosynthetic organ in the study was aimed at the formation of a good total biomass. Both cultivars formed grain nature, glassiness, starch and protein quantity, gluten quantity at the level of State standards for strong and valuable wheat; gluten quality corresponded to the 2 nd group. Indicators of the ear structure of Almaly cultivar were higher than indicators of SWW 2/127 cultivar. Productivity of Almaly cultivar was 91.8 centners per a hectare, seed sowing norm was 2 million grains per a hectare; productivity of SWW $2 / 127$ cultivar at the same norm of seed sowing was 77.4 centners per a hectare.

Key words: winter common wheat, drip irrigation, anatomical structure, grain quality, productivity.

Language: English

Citation: Yeraliyeva ZM, Kunelbayev M, Baitasheva G, Kydyrov A (2017) THE INFLUENCE OF AGRICULTURAL TECHNOLOGY ON THE CULTIVATION OF WINTER WHEAT DURING DRIP IRRIGATION IN THE SOUTHEAST OF KAZAKHSTAN. ISJ Theoretical \& Applied Science, 11 (55): 39-46.

Soi: http://s-o-i.org/1.1/TAS-11-55-7 Doi: crossef https://dx.doi.org/10.15863/TAS.2017.11.55.7
\end{abstract}

\section{I.INTRODUCTION}

The priorities of the Concept of transition to a "green economy" is a more efficient use of water and land resources management, improving water security. According to the concept by $2030,15 \%$ of areas under crops in Kazakhstan will be transferred to water-saving technologies. The increase in grain production and improve its quality remains a major concern in agriculture.Kazakhstan traditionally is a major area of production of high-quality grain strong and valuable wheats. In the south and south-east of Kazakhstan's main grain crop is winter wheat. The area beneath it in recent years is in the order of 800-
850 thousand ha, or $80 \%$ of the total area under crops in this large region. Gross output of winterwheat in the average for the last 7 years has made about 800 thousand. Tones with the average yield of grain 25$27 \mathrm{c} / \mathrm{ha}$. The territory of Kazakhstan is characterized by a variety of climatic zones, from Mid and mountain chernozem soils with annual rainfall of 500-700 mm per year to desert-steppe zones, submitted calcareous, ordinary and light gray soils, with a rainfall of about $180-280 \mathrm{~mm}$ per year and extreme instability of meteorological conditions over the years and seasons of the year (S\&P Dow Jones Indices, 2012) [1]. Strategy in crop implies, first of all, diversification of production, the increase in 
agricultural production volumes by switching to evidence-based moisture-saving technologies of cultivation of crops, to ensure the rational use of agricultural land, the involvement of the agricultural turnover of new and currently unused land (Program for development of agriculture Karabayev et al., 2009)[2] Kazakhstan, possessing rich land resources, high scientific potential and developed structure of the economy has a tremendous opportunity to increase agricultural production, and become the world's leading exporter of high-quality grain and other agriculturalproducts. Kazakhstan is now considered as the most important region of the world food security the world's population. According to the official analytical data in 2025 in the world must be made 3 bln. Tons of grain crops for 8 billion of the world population. To achieve this, the annual growth in production the most important food crops wheat, should be $2 \%$ (compared to the current annual growth rate of $1.3 \%$ ). And this should be done against the backdrop of the rise of influence of adverse factors, such as the reduction of water availability, drought, temperature rise, land degradation, the emergence of new highly dangerous pathogens, the increase in the use of plant products to biofuels and livestock needs.

There is no doubt that overcoming these negative factors and sustainable development of agricultural production, both in Kazakhstan and in the world to a great extent depend on the development of new technologies and scientific sphere. In today's world of technology and innovation are key to the country's competitiveness and food security (Sydyk, 2014)[3].

Today, the water deficit in Kazakhstan is more than $20 \%$ in the future with the growth of consumption and the reduction of water shortage will only increase. Of particular concern are the prospects for water supply to southern regions of Kazakhstan due to the high dependence on cross border issues, deterioration of irrigation systems, and unsustainable agricultural production. Therefore, one of the priority directions of development of agriculture of irrigated zones of the Republic is the transition to watersaving technologies. Drip irrigation - an economically sound and environmentally safe method of irrigation, in which water is served in small portions to the roots of the plants from aboveground pipelines through the slit-like opening in the irrigation tapes laid in the ground or on the surface. Thus, direct pretrial soil moisture allows 2-3 times to reduce the cost of water, so there is an opportunity to engage in crop production, even in areas where it was not possible (Reinders, 2006)[4] for the lack of water resources. Drip irrigation main priority over other irrigation methods considered significant saving irrigation water (about 50-90\%). Drip irrigation is currently one of the rapidly developing methods of irrigation. In the last twenty years, the area occupied by drip irrigation, expanded by more than 6 times and at the present time in the world in the order of 6.1 million ha (Amarasinghe et al., 2007)[5]. Different variants of water resources management in different regions has forced economists and scientists to critically analyze the shortage of water and water resources. By 2025, a study conducted by the International Institute for Water Resources (IWMI) management, shows that, by increasing irrigation efficiency of about $50 \%$ growth in demand for water can be achieved (Narayanamoorthy, 2003)[6]. Since the late seventies, the importance of sustainable use of water resources in agriculture, gave a series of water management have been introduced to improve the efficiency of water use, especially in the use of surface water for irrigation. The net impact of increasing water efficiency is not very impressive on the various strategies that have introduced their own purposes (International Grain Council, 2013)[7]. Wheat (Triticum aestivum L.) is one of the most important, basic food grain human race. During 2011-12, India produced 94.88 million tonnes of wheat which is about 13.53 per cent of world production (Zerihun et al., 2005)[8]. Currently, about $66.5 \%$ of the large area in India is irrigated with very poor water use by wheat harvest (Rosegrant, 1997; INCID, 1994)[9]. The country supports the 3 percent ofthe world's waters and 16 percent of the world's human population and 20 percent of livestock (Chauhan and Yadav, 2012)[10]. With changing lifestyles and increasing water consumption agriculture is under threat. Irrigation method or Micro Irrigation (MI) is one of the main controlling factors for the control of water in agriculture in India. To help achieve a yield increase of up to $100 \%$ and water savings up to $40-80 \%$ of the most effective of allmethods of irrigation is drip irrigation. In (Burney, The Study of Agricultural Techniques of Cultivation of New Varieties of Winter Wheat Under 781 2009; Kumari et al., 2014)[11] showed an increase in the efficiency of the use and conservation of fertilizers, pesticides under drip irrigation system. Drip irrigation can be practiced successfully with a wide variety of irrigation, especially in crops of fruit vegetables, but on the other hand, limited studies have been performed in field crops such as wheat. In comparison with surface irrigation of wheat, drip irrigation saves more than 20 percent of irrigation water (Kharrou et al., 2011[12]), as well as mandatory to produce $1 \mathrm{~kg}$ of wheat about 1,000 lit of irrigation water (Hoff, 2004). Various positive and negative qualities under drip irrigation has a significant impact on society in general (Dhawan, 2000; Joseph and Muthuchamy, 2014)[13]. The applicability and success of drip irrigation should be verified by region, type of soil, climate and management of irrigation systems for irrigation of intensive crops, which were held in (Abdelraouf et 
al., 2011; Arafa et al., 2009; Alam et al., 2000; Suarez- Rey et al., 2000; Rahman, 2009; Camp, 1998)[14]. The main consumer of water resources in Kazakhstan, as in other countries of the Central Asian region is irrigation, which accounts for over $70 \%$ of the total capacity of surface runoff. Almost the entire territory of the Republic holds tight water situation due to lack of water resources and pollution of water sources. The annual water deficit in Kazakhstan is $2-3 \mathrm{~km} 3$. water-dependent problem is a threat to the national security of Kazakhstan due to the occurrence of interstate and regional conflicts (transboundary rivers). The main water consumer is agriculture, which consumes more than $60 \%$ of the sta. In this regards, the obvious relevance of acquired research aimed at developing farming systems that ensure efficient use of natural and water resources, improving the productivity of irrigated arable land and are of strategic importance, both nationally and internationally. There is a need for intensification of agriculture, the use of new breakthrough scientific technologies of cultivation of agricultural crops. Therefore, these studies have the priority in design engineering evaluations, and determine the proposed alternative system of irrigation on the yield of wheat in the agricultural field volume of water, or more than $10.2 \mathrm{~km} 3$.

\section{II.MATERIALS AND METHODS}

Our studies were carried out in 2014-2015 in the demonstration site "Ushkonyr" Kazakh Scientific Research Institute of Agriculture and Plant. The soilstudied varieties - light chestnut. The objects of the study were two new lines grades SWW 1/904, SWW 1/97 of winter wheat (Triticum aestivum L.). Overall experience area -0.10 ha. Area $50 \mathrm{~m} 2$ plots, repeated three times. Methods: Field and laboratory. Phenological observations were made by the procedure of the State Commission for Variety Testing crops. Measurement of biometric data was carried out by conventional methods. Before harvesting with two replicates selected vegetable samples with the definition of the main elements of the structure of the crop. Accounting for the harvest produced by direct pushed plot harvester "SAMPO250". Calculation of economic efficiency is made at cost per unit of production per hectare area in accordance with the actual monetary and energy costs on the cultivation of crops studied. Irrigation system. Drip irrigation system includes [18]:

- Storage of irrigation water (Fig. 1);

- Water pump gasoline capacity of $15 \mathrm{~m} 3 / \mathrm{h}$

(Figure 2);

- Filter sand (Fig. 3);

- Disc filter (Fig. 4);

- Injector for feeding fertilizer;

- Line pipe (Fig. 5);

- Distribution pipes (Fig. 6);

- Irrigation tape with drippers, surface drip irrigation (Fig. 7).

\section{III.RESULTS AND DISCUSSION}

In 2014, the varieties were sown 2 new lines of winter wheat super SWW 1/904, SWW 1/97. Sowing of winter wheat cultivar samples was conducted Fig. 1. Storage of irrigation water October 18, 2016, i.e., in later planting dates, with an average daily temperature of the air $13,30 \mathrm{~S}$, maximum and minimum 21,40S 6,40S. Autumn from October 18 to 26 October was favorable for thermal and water regime. The sum of the average daily temperature was $+118,60 \mathrm{~S}$, and the amount of moisture reserves from 1 to 26 October was $103.5 \mathrm{~mm}$ smooth. On October 27 , there was a decrease in temperature to a different $-3,90 \mathrm{~S}$, due to loss of a significant amount of precipitation in the form of rain, followed by a transition in the snow. Under these agrometeorological environmental conditions for the winter wheat was observed inhibition of the production process. Later in November, and the air temperature was lower thresholds, so due to the late date of sowing of winter wheat seedlings went into the winter. However, under favorable overwintering conditions, ie, warm, snow, short winter, all together had a positive impact on the degree of preservation. 


\begin{tabular}{|c|c|c|c|c|c|c|}
\hline Impact Factor: & $\begin{array}{l}\text { ISRA (India) } \\
\text { ISI (Dubai, UAF } \\
\text { GIF (Australia) } \\
\text { JIF }\end{array}$ & $\begin{array}{l}=1.344 \\
=0.829 \\
=0.564 \\
=1.500\end{array}$ & $\begin{array}{l}\text { SIS (USA) } \\
\text { PИНЦ (Russia) } \\
\text { ESJI (KZ) } \\
\text { SJIF (Morocco) }\end{array}$ & $\begin{array}{l}=0.912 \\
=0.207 \\
=\mathbf{3 . 8 6 0} \\
=\mathbf{2 . 0 3 1}\end{array}$ & $\begin{array}{l}\text { ICV (Poland) } \\
\text { PIF (India) } \\
\text { IBI (India) }\end{array}$ & $\begin{array}{l}=6.630 \\
=1.940 \\
=4.260\end{array}$ \\
\hline
\end{tabular}

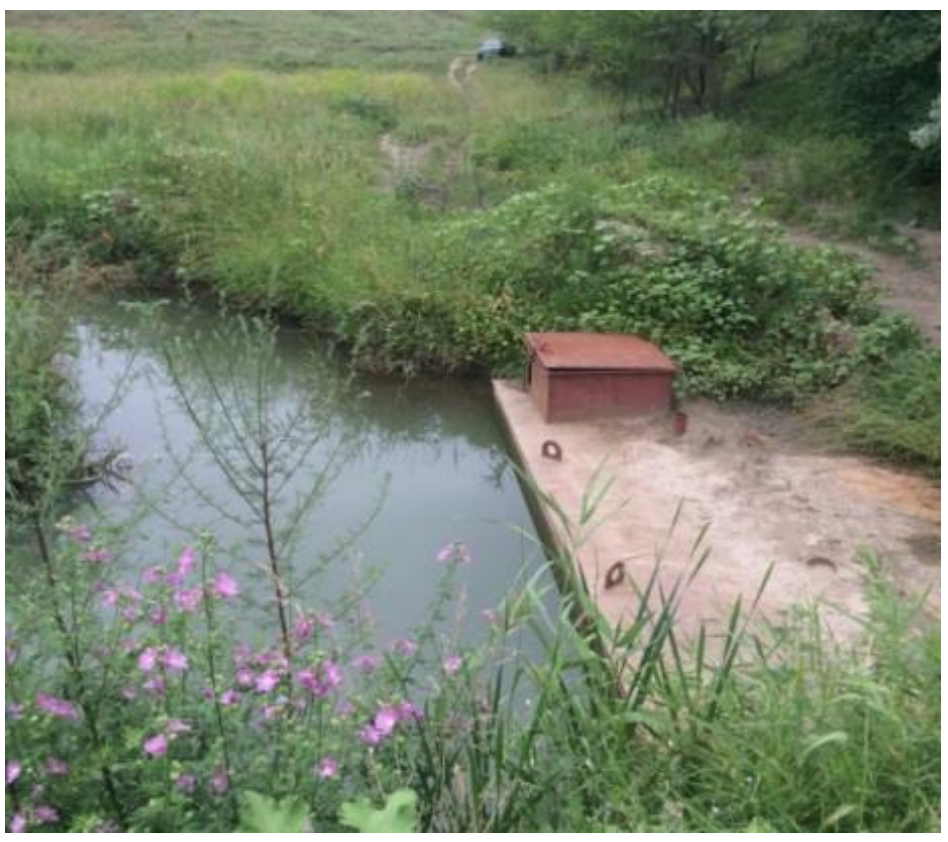

Figure 1 - Storage of irrigation water.

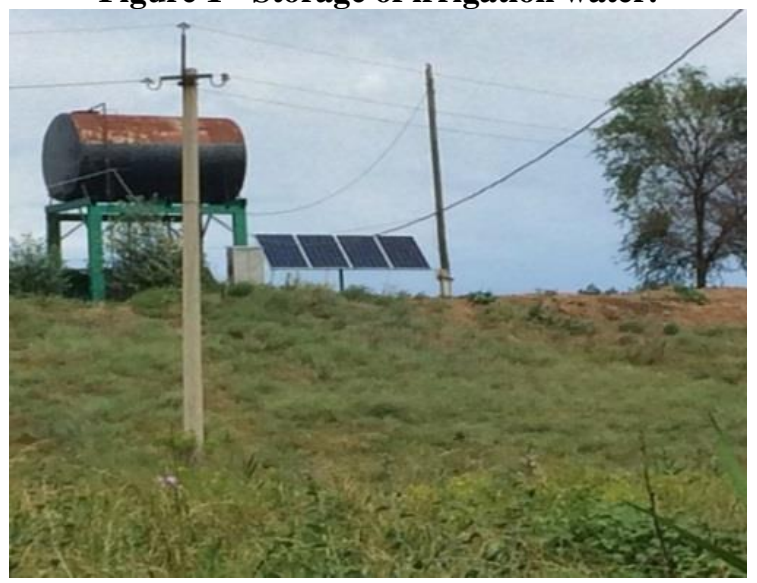

Figure 2 - Water pump gasoline capacity of $15 \mathrm{~m} 3 / \mathrm{h}$

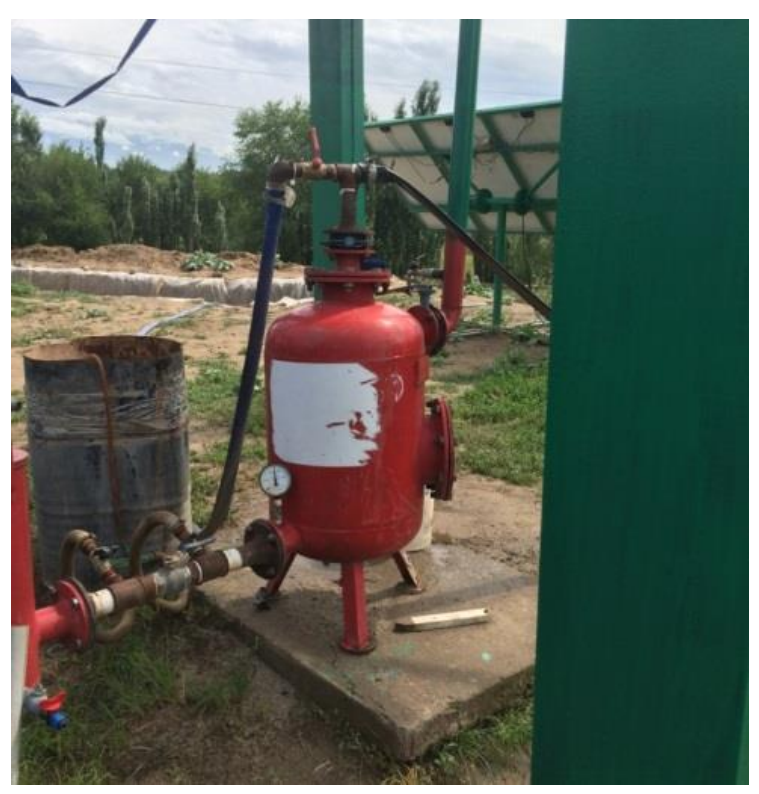




\begin{tabular}{l|lrl|l|ll} 
& ISRA (India) & $=\mathbf{1 . 3 4 4}$ & SIS (USA) & $=\mathbf{0 . 9 1 2}$ & ICV (Poland) & $=\mathbf{6 . 6 3 0}$ \\
Impact Factor: & ISI (Dubai, UAE) $=\mathbf{0 . 8 2 9}$ & PUHU (Russia) $=\mathbf{0 . 2 0 7}$ & PIF (India) & $=\mathbf{1 . 9 4 0}$ \\
& GIF (Australia) & $\mathbf{0 . 5 6 4}$ & ESJI (KZ) & $=\mathbf{3 . 8 6 0}$ & IBI (India) & $\mathbf{4 . 2 6 0}$
\end{tabular}

Figure 3 - Filter sand

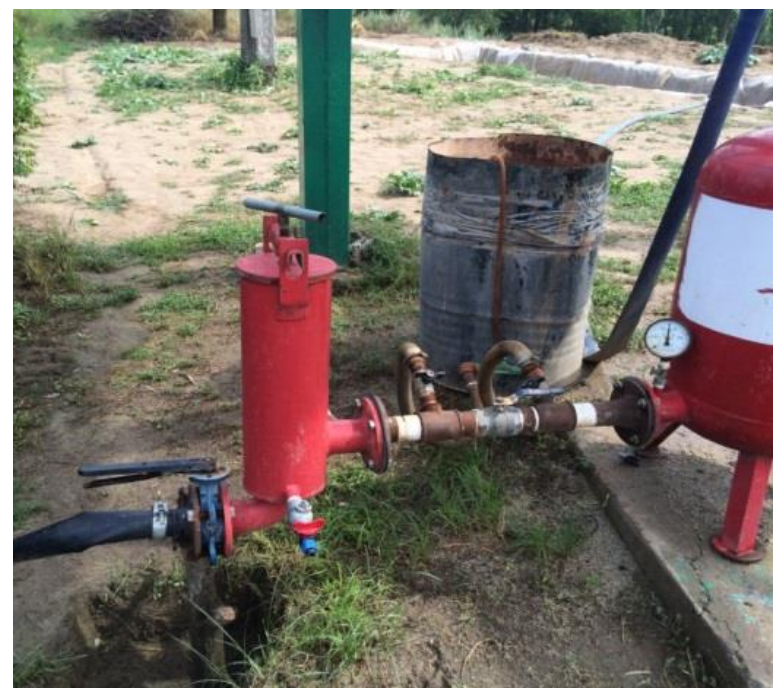

Figure 4 - Disc filter

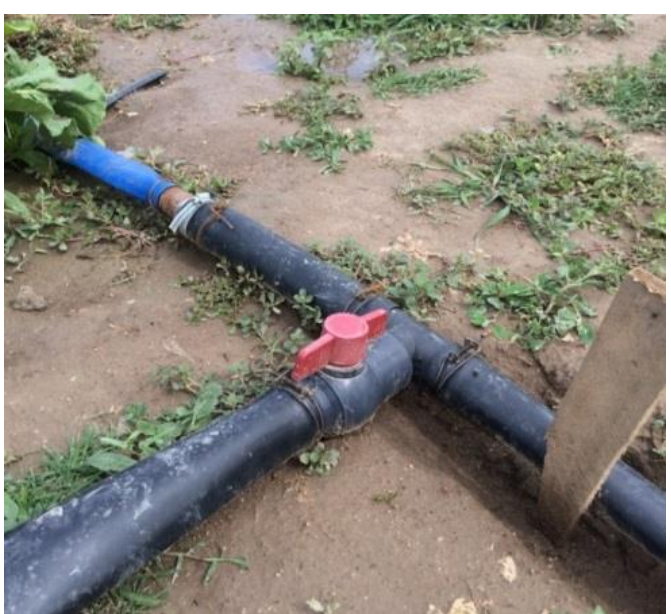

Figure 5 - Line pipe

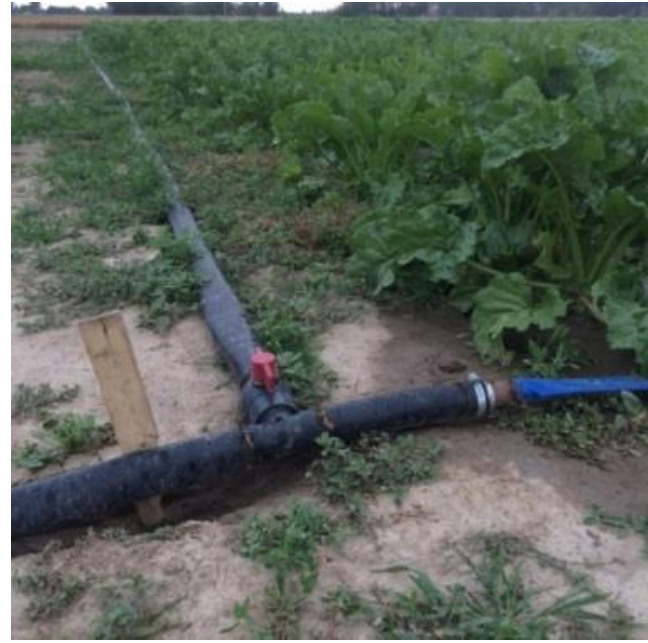

Figure 6 - Distribution pipes 
The Study of Agricultural Techniques of Cultivation of New Varieties of Winter Wheat Under 783 of seedlings, and eventually the formation of the optimal density agrobiocenoses stalks (Figure 1, 2).To generate high yields of winter wheat agrobiocenosis must create a strong area of assimilation for surface capable to capture and absorb the energy of the sun with high efficiency lamps (Figure 8, 9). Grade super wheat samples SWW $1 / 904$ and $1 / 97$ had SWW foliage area 61.12 and 64.08 thousand $\mathrm{m} 2 / \mathrm{ha}$, respectively. This allowed them to be used in the coming vegetation sun energy to $2.59 \%$ and $2.66 \%$ FAR. It should be noted that the characteristic of the sheet to create a larger area for the super wheats. Super wheat SWW SWW 1/904 and 1/97, having a large size of the photosynthetic organ, dry when it exceeded the value of the data of super wheat SWW 1/904 $2.4 \mathrm{~cm}$. The number of spikelet's in experience ranged from 32 up to 37 pieces, and the number of grains per ear from 38 to 45 pieces. Moreover, in both cases the highest values (37 and 45 pcs.) Super wheat accessions SWW 1/97 were installed[18].

Anatomical researches. Measurement of the biometric indicators was carried out by the standard methods. Fixation of over ground and underground parts of plants was carried out in the preserving mixture alcohol-glycerin-water (1:1:1) [15]. Temporary anatomical specimens were done manually with use of the blade of the ordinary razor. The slices in 10-15 microns thickness were kept in glycerin [16]. The prepared temporary specimens were used for making the microphotography and carrying out the morphometric analysis using the microscope Micros Austria MCX100 with the video camera 519CU 5.OM CMOS (lens $10 \times / 0.25$, magnification $100 \times)$. Statistical processing of morphometric indicators was done via standard methods [17].

The analysis of grain quality was carried out in laboratory of technological evaluation of grain of the LLP "Kazakh Research Institute of Agriculture and Plant Growing". The indicators of grain quality were found by the methods presented in the State Standards (GOST): mass of 1,000 grains; grain nature; glassiness; humidity of grain; protein's quantity; starch's quantity; quantity and quality of gluten.

Prior to get the crops the experimental samples of two cultivars were selected for definition of basic elements of the harvest structure. Harvesting the wheat from the experimental sites was carried out by the mono-phase combine "SAMPO-250" (figure 7).

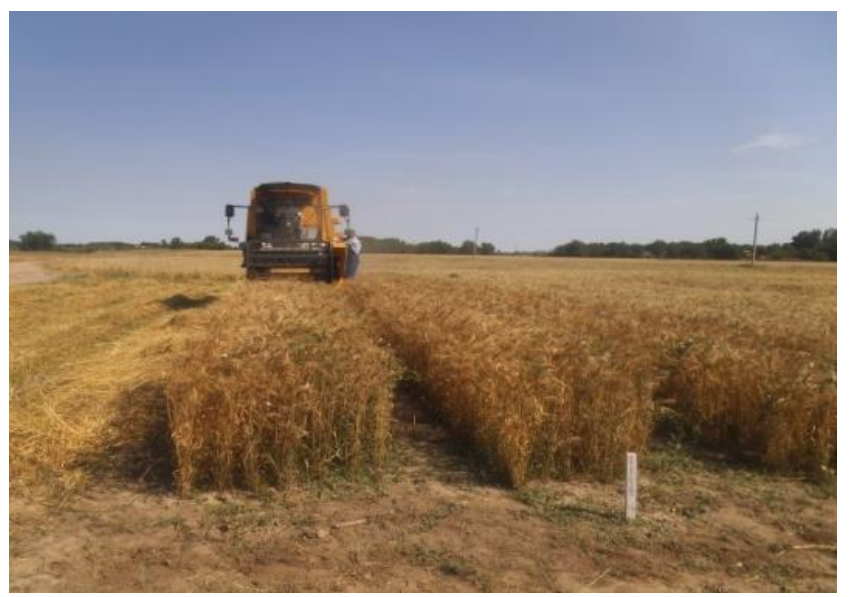

Figure 7 - Harvesting the cultivars of winter common wheat Almaly and SWW 2/127, 2016

\section{IV.RESULTS AND DISCUSSION}

It is known that the stem of wheat is characterized by primary anatomical structure. It has the plump peripheral part and a cavity lacuna in the center. A peripheral part is formed by the epidermis which is poor notable against the background of a sclerenchyma, the primary bark and the central cylinder. The central cylinder consists of the closed conducting bundles, the ring of the mechanical tissue (sclerenchyma) and the storage parenchyma [45]. The epidermis consists of the identical cells located densely in one chain, and on the surface of the external epidermis the cuticle is formed. The sclerenchyma cells forming the mechanical tissue adjoin to the epidermis. The mechanical tissue consists of the small cells with a thick cell wall which tightly adjoin to each other and are arranged in several rows. Behind the mechanical tissue the colourless parenchyma is located. The parenchyma is 
formed by multi-scale large cells with a thin cytoderm (cell wall). There is no parenchyma in the centre and the lacuna is formed. Conducting bundles are divided into large and small ones. Small conducting bundles are located in the mechanical tissue distantly from each other. They provide metabolism in the cells of the primary bark. In the main tissue closer to the center there are large conducting bundles, they form the regular circle. All conducting bundles are collateral and closed. The metaxylem is presented by two large porous vessels; among these vessels a small number of the fibrous tracheids are located.

As a result of cells' growth and stem's thickening the stem's core is torn and the lacuna that is the feature of many cereals is formed. This stem is called a culm.

It was noticed that the new cultivar of super wheat SWW 2/127 differs from the standard cultivar Almaly, its stem is higher (figure 3). The stem height of Almaly cultivar was $110 \mathrm{~cm}$, the stem height of SWW 2/127 cultivar was $120 \mathrm{~cm}$.
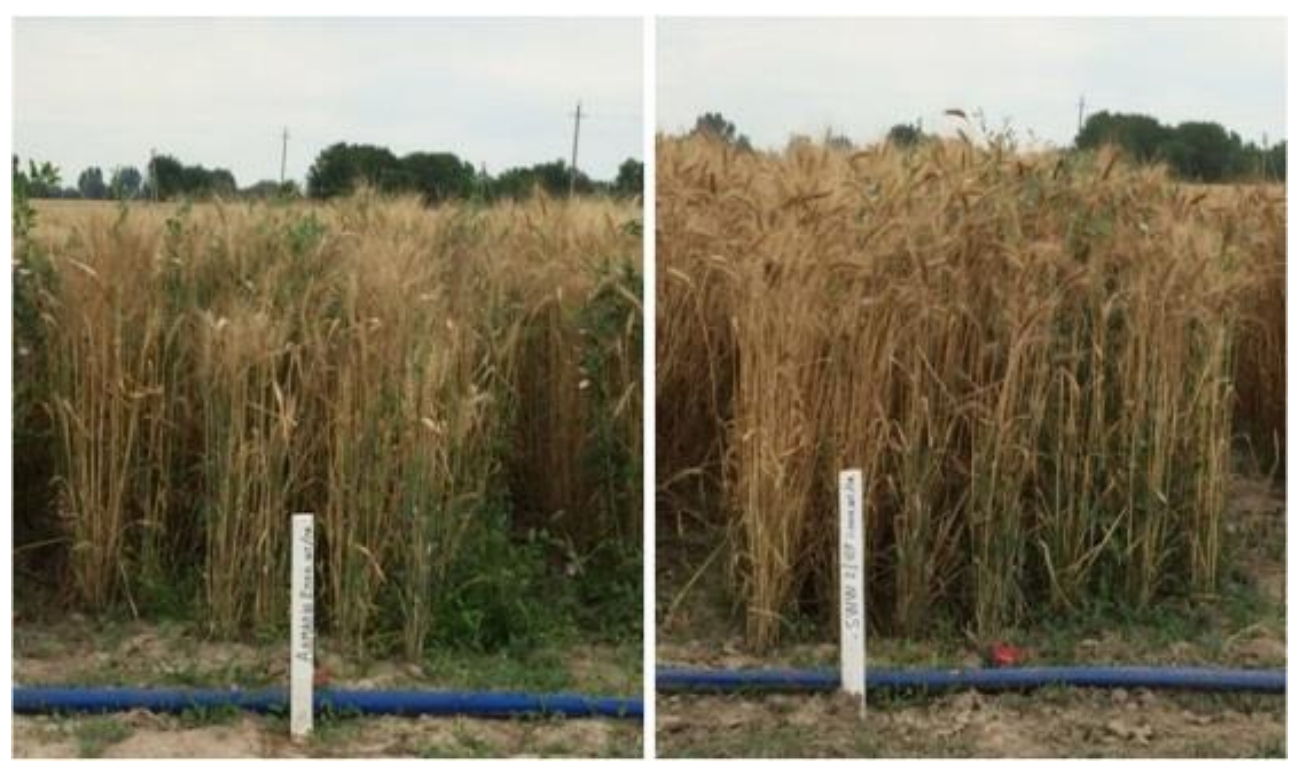

Figure 8 - The winter common wheat in the phase of full maturity, Ushkonyr, 2016: Almaly cultivar is on the left; SWW 2/127 cultivar is on the right

The results of measurement of biometric indicators of the anatomical structure of the stem of the studied cultivars are presented in table 2.

Having compared the studied cultivars of winter common wheat we noted that the highest productivity was provided by the zoned, domestic cultivar Almaly. At norm of seed sowing in 2 million grains per a hectare and optimum conditions of mineral nutrition with application of $\mathrm{N}_{120} \mathrm{P}_{60}$ this cultivar formed 91.8 centners per 1 hectare.

The studied cultivars formed high crops when using surface drip irrigation as harvest accounting had shown. At the total background of mineral nutrition, $\mathrm{N}_{120} \mathrm{P}_{60}$, the studied cultivars formed the grain yield from 77.4 to 101 centners per a hectare.

The high rate of productivity at the same time depended both on the norm of seed sowing as on the biological features of the studied cultivars having demonstrated their plasticity.
On the basis of the above stated it is possible to conclude that high rates of productivity of two studied cultivars of winter common wheat Almaly and SWW 2/127 were formed under the influence of several factors such as: anatomic features of a stem; plasticity of the cultivar; the optimally chosen norm of seed sowing and using the drip irrigation technology.Study of the reaction of new winter wheat varieties under drip irrigation showed that the super wheat SWW SWW 1/904 and 1/97, having a large size of the photosynthetic organ, dry biologically harvest reached 167,2-172,8 c/ha.

\section{V.CONCLUSION}

The comparative data of indicators of the anatomical structure of the stem, quality of grain, the structural analysis of the ear and productivity of two cultivars of winter common wheat grown up with use of drip irrigation technology in the conditions of the southeast of Kazakhstan, received as a result of 
carrying out the researches allow us to draw the following conclusions:

SWW 2/127 cultivar in the third internode had bigger indicators of thickness of epidermis, length and width of the large carrying bundle, lengths and width of xylem, thickness of the parenchyma's cell and stem thickness than Almaly cultivar had; but SWW 2/127 cultivar had smaller indicators of thickness of mechanical tissue and primary bark, length and width of small carrying bundles than Almaly cultivar had.

Almaly cultivar had larger total number of small conducting bundles of primary bark than SWW 2/127 cultivar had; and Almaly cultivar had fewer total number of large conducting bundles located in the main tissue than SWW 2/127 cultivar had.

Determination in winter wheat in super photosynthetic organ study was aimed at the formation of a good total biomass. Research has established in the cultivation of new varieties of winter wheat under drip irrigation, provided the greatest yield grade line of super wheat SWW 1/904. When seeding rate of 4 million/ ha and the optimal conditions of mineral nutrition with the introduction N120P60 grade grain formed 95.2 centners per 1 hectare.

\section{References:}

1. (2012) S\&P Dow Jones Indices. Available: https://us.spindices.com/ourcompany/ourhistory/ (Accessed: 10.11.2017).

2. Karabayev M., Wall P., Brown J., Morgunov A. (2009) Main activities of CIMMYT in the resource-saving technologies in Kazakhstan.Know-Teel and crop rotation - the basis of the agrarian policy of supporting sustainable agriculture for sustainable production intensification. Shortandy, Astana, $39-45$.

3. Sydyk D.A. (2014) Resource-saving technologies of cultivation of winter wheat in the conditions of irrigated agriculture in South Kazakhstan. Shymkent.

4. Reinders F.B. (2006) Micro-irrigation: world overview on technology and utilization.Keynote address at the opening of the International Micro-Irrigation Congress in Kuala Lumpur, Malaysia.

5. Amarasinghe U.A., Shah T., Turral H., Anand B.K. (2007) India's water future to 2025-2050: Business-asusualscenario and deviations. IWMI Research Report123. International Water Management Institute,Colombo, Sri Lanka.

6. Narayanamoorthy A. (2003) Averting water crisis by drip method of irrigation: a study of two water intensivecrops. Indian J Agr Econ. 58 (3): 427-437.

7. (2013) International Grain Council. Market report on grain, GMR-435.2013.

8. Zerihun D., Sanchez C.A., Farrell-Poe K.L., Yitayew M. (2005) Analysis and design of border irrigation systems. Transactions of the ASAE, American Society of Agricultural Engineers. 48(5): 1751-1764.

9. Rosegrant W.M. (1997) Water resources in the twenty-first century: challenges and implications for action, food, agriculture and the environment discussion paper 20.
International Food Policy Research Institute, Washington D.C., USA.

10. Chauhan R.P.S., Yadav B.S. (2012) Studies on crop yield responses to deficit irrigation and levels of nitrogen in wheat, water, energy and food security: call for solutions, India Water Week, New Delhi.

11. Kumari R., Kaushal A., Singh K.G. (2014) Water use efficiency of drip fertigated sweet pepper under the influence of different kinds and levels of fertilizers. Indian Journal of Science and Technology. 7 (10): 1538-1543.

12. Kharrou M.H., Salah R., Ahmed C., Benoit D., Vincent S., Michel L., Lahcen O., Lionel, J. (2011) Wateruse efficiency and yield of winter wheat under efferent irrigation regimes in a semi-arid region. Agri Sciences. 2(3): 273-282.

13. Dhawan B.D. (2000) Drip irrigation: evaluating returns. Economic and Political Weekly. 35 (42) : 3775-3780.

14. Abdelraouf R.E., Refaie K.M., Hegab I.A. (2011) Effectof drip lines spacing and adding compost on the yield and irrigation water use efficiency of wheat grown under sandy soil conditions. Journal Appl Sci Res. 9(2):11161125.

15. Permyakov A.I. (1988) Microtechnics. Moscow, pp.: 62.

16. Prozina M.N. (1960) Botanical Microtechnics. Moscow, pp.: 208.

17. Lakin G.F. (1990) Biometry. Moscow, pp.: 352.

18. Yeraliyeva Zh.M., Kunelbayev M., Ospanbayev Zh., Kurmanbayeva M.S.,

19. Kolev T.P., Kenesbayev S.M., Newsome A.S. (2016) The study of agricultural techniques of cultivation of new varieties of winter wheat under drip irrigation. Asian jr. Of microbiol. Biotech. Env. Sc. Vol. 18, no. (3) : 2016 : 779785 